\title{
Extracapsular cataract extraction in horses by nuclear fragmentation using adapted instruments
}

\author{
[Facectomia extracapsular em eqüinos mediante núcleo fragmentação, com o emprego \\ original de instrumentais adaptados] \\ A.L.G. Souza ${ }^{1}$, A.F.P.F. Wouk $^{2}$, I. Deconto ${ }^{2}$, J.H. Perotta ${ }^{1}$, J.L. Laus ${ }^{3 *}$ \\ ${ }^{1}$ Aluno de pós-graduação - FCAV-UNESP - Jaboticabal, SP \\ ${ }^{2}$ Universidade Federal do Paraná - Curitiba, PR \\ ${ }^{3}$ Faculdade de Ciências Agrárias e Veterinárias - UNESP \\ Via de Acesso Prof. Dr. Paulo Donato Castellane, $\mathrm{s} / \mathrm{n}^{\circ}$ \\ 14884-900 - Jaboticabal, SP
}

\begin{abstract}
It was studied the nuclear fragmentation technique for lens extraction in six adult horses using adapted surgical instruments. Postoperative assessment revealed a reduction of intraocular pressure in all animals during the first postoperative days, as well as varying degrees of photophobia, blepharospasm, corneal edema, and iridocyclitis. Fibrin formation mainly located in the axial portion of the pupilla was noted in most cases, affecting or impairing vision.
\end{abstract}

Keywords: horse, cataract, surgery

\section{RESUMO}

Estudou-se a técnica de núcleo-fragmentação para a extração da lente em seis eqüinos adultos, utilizando-se instrumentais cirúrgicos adaptados. Nas avaliações pós-operatórias, verificou-se diminuição da pressão intra-ocular, em todos os animais, nos primeiros dias de pós-operatório e, ainda, fotofobia, blefarospasmo, edema de córnea e iridociclites, em graus diversos. Observou-se produção de fibrina que, na maioria dos casos, localizava-se na porção axial da pupila, dificultando ou impedindo a visão.

Palavras-chave: eqüino, catarata, cirurgia

\section{INTRODUCTION}

Cataracts are opacities of the lens. In horses, it can occur secondary to intraocular inflammation, which may be the most common etiology, secondary to trauma, or be inherited. This opacity may be present at birth or probably more commonly be acquired in early neonatal or later adult life.

Cataracts may result in visual impairment ranging from little effect on vision to total blindness, depending upon the extent of lens opacification. Horses with dense cataracts become impaired to the extent that they cannot safely be ridden or used for their intended purpose. In view of the size of these animals, cataracts causing blindness may render the horse unsafe to be around and make the animal prone to severe self-injury. For this reason there have been many attempts and several reports of cataract surgery in horses (Whitley et al., 1983; Whitley et al., 1990).

Recebido em 29 de junho de 2006

Aceito em 25 de novembro de 2008

*Autor para correspondência (corresponding author)

E-mail: jllaus@fcav.unesp.br 
Cataract surgery is less commonly performed in horses when compared with the frequency of this surgery in dogs. This may be due to the fact that cataracts are reported less frequently in horses, as compared with corneal disease or uveitis. There also appears to be a lower incidence of inherited cataracts in this species compared with dogs and cats (Whitley et al., 1983; Diziezyc et al., 1991). Surgery is also performed less frequently, because of the greater potencial complications of intraocular surgery in horses. Furthermore, it is difficult to assess the usefulness of aphakic horses (Hardman et al., 2001).

Most veterinary ophthalmologists recommend cataract extraction, notably in young foals, before the age of six months. Intervention in foals is more feasible because the small eyeball permits the use of surgical equipment and instruments designed for humans (Brooks, 2003; Wouk et al., 2003; Matthews, 2004; Turner, 2004).

Techniques described to remove cataracts in the horse have included extracapsular and intracapsular approaches with aspiration, and phacoemulsification and aspiration. Phacoemulsification and aspiration have been the technique most often described, but requires specific equipament.

Technological and pharmacological advances have allowed lens extraction in horses to become a feasible alternative that permits the animal to return to its normal activities. However, uveal inflammation still represents a great threat to the success of surgery (McLaughlin et al., 1992); thus requiring the search for new techniques.

The objective of the present study was to evaluate the advantages of an alternative technique to extract cataract in adult horses based on phacofragmentation and to study the viability of the application of instruments adapted to the dimensions of their eyes.

\section{MATERIAL AND METHODS}

Six adult male or female horses of different breeds, identified with numbers from one to six, were submitted to unilateral nuclear fragmentation of the lens. Ophthalmic examination consisted of the evaluation of the pupillary ${ }^{1}$, right and consensual light reflexes, menace reflex (blink reflex) and obstacle test, slit-lamp biomicroscopy ${ }^{2}$, applanation tonometry $^{3}$ under topical anesthesia with proxymetacaine hydrochloride ${ }^{4}$, and direct monocular $^{5}$ and indirect binocular ophthalmoscopy ${ }^{6}$ under mydriasis induced by instillation of tropicamide ${ }^{7}$. The exams were performed up to 60 days after surgery. The following parameters were qualitatively and quantitatively evaluated: epiphora and secretions, pupillary diameter, aspect and depth of the anterior chamber and iris contour, accumulation of abnormal substances in the anterior chamber (flare-hyphema-hypopyon), corneal edema, corneal ulcerations, posterior capsular cataract, vitreous chamber abnormalities, retinal exudate, and abnormalities of the optic disk and papilla. These signs was classified as absent, mild $(+)$, moderate $(++)$, and intense $(+++)$.

The animals received eyedrops containing atropine $^{8}$, phenylephrine ${ }^{9}$, and tobramycin ${ }^{10}$ at regular intervals of $6 \mathrm{~h}$ on the day before surgery, and oral acetyl salicylic acid ${ }^{11}$ in a single dose $(5 \mathrm{mg} / \mathrm{kg}), 24 \mathrm{~h}$ before the intervention. On the day of surgery, one hour before the procedure, eyedrops containing tobramycin ${ }^{10}$ (once), diclofenac sodium ${ }^{12}$, and prednisolone ${ }^{13}$ (twice, at 30-min intervals); and tropicamide ${ }^{7}$ and phenylephrine $^{9}$ (six times, at 10-min intervals) were instilled.

After a $12 \mathrm{~h}$ fast water and food fasting period, the animals were premedicated with $0.07 \mathrm{mg} / \mathrm{kg}$ acepromazine $^{14}$ intravenously administered. After 20min, anesthesia was induced by intravenous administration of $80 \mathrm{mg} / \mathrm{kg}$ guaiacol glyceryl ether ${ }^{15}$ ( $10 \%$ solution), followed by the intravenous administration of $5 \mathrm{mg} / \mathrm{kg}$ thiopental

\footnotetext{
${ }^{1}$ Transilluminator 76600 - WelchAllyn

${ }^{2}$ Portable Slit Lamp SL-14 - Kowa ${ }^{\circledR}$

${ }^{3}$ Tono-Pen ${ }^{\mathrm{TM}} \mathrm{XL}-$ Mentor $^{\circledR}$

${ }^{4}$ Anestalcon $0.5 \%{ }^{\circledR}$ - Alcon

${ }^{5}$ Mini 2000 direct ophthalmoscope - Heine ${ }^{\circledR}$

${ }^{6} \mathrm{OHD}-4.3$ indirect ophthalmoscope - Eyetec ${ }^{\circledR}$

${ }^{7}$ Mydriacyl $^{\circledR}$ - Alcon

${ }^{8}$ Atropine $1 \%{ }^{\circledR}$ - Allergan

${ }^{9}$ Phenylephrine $10 \%{ }^{\circledR}$ - Ophthalmos

${ }^{10}$ Tobrex $^{\circledR}$ - Allergan

${ }^{11} \mathrm{AAS}^{\circledR}$ - Snofi - Synthelabo

${ }^{12}$ Voltaren DU ${ }^{\circledR}$ - Flasks - Novartis

${ }^{13}$ Predfort ${ }^{\circledR}$ - Allergan

${ }^{14}$ Acepram 1\% ${ }^{\circledR}$ - UNIVET

${ }^{15}$ Guaiacol glyceryl ether - Henrifarma
} 
sodium $^{16}$. Anesthesia was maintained with halothane ${ }^{17}$ vaporized in oxygen $(10 \mathrm{ml} / \mathrm{kg} / \mathrm{min})$ in a semi-closed circuit.

For surgery, the animal was positioned in right lateral decubitus for accessing the contralateral eye. After trichotomy of the surgical area, the periorbital and ocular and conjunctival surfaces were disinfected with polyvinylpyrrolidone iodine $^{18}$ diluted to $1: 25$ and $1: 100$ in saline, respectively.

A 5x magnifying loupe was used to amplify the surgical field. An incision of approximately $2 \mathrm{~cm}$ was made on the clear transparent cornea at 10 to 11 o'clock position with a $\mathrm{n}^{\mathrm{o}} 11$ surgical knife. The anterior chamber was then filled with Trypan blue ${ }^{19}$ to stain the anterior crystalline capsule. The corneal incision was enlarged to $3.5 \mathrm{~cm}$ using corneal (right and left) forceps. Two minutes after application of the dye and its contact with the anterior capsule of the lens, the remaining dye was removed by washing the anterior chamber with $500 \mathrm{ml}$ lactated Ringer's solution $^{20}$ supplemented with $0.8 \mathrm{ml}$ adrenaline ${ }^{21}$ and $0.8 \mathrm{ml}$ heparin ${ }^{22}$. The anterior chamber was then filled with a viscoelastic substance (methylcellulose) $^{23}$. A 29-mm long $27 \mathrm{G}$ gingival needle $^{24}$ (Girotto et al., 2000) with a properly bent tip comprising the total diameter of the lens (Fig. 1) was used to produce a capsulotomy. A continuous curvilinear capsulorrhexis was performed with an Utrata forceps.

For nuclear fragmentation, a cannula coupled to a 5-ml syringe filled with lactated Ringer's solution $^{20}$ containing adrenaline ${ }^{21}$ and heparin ${ }^{22}$ was introduced against the anterior side of the posterior capsule, and hydrodissection of the lens nucleus was performed. The nucleus was then immediately divided into three fragments using a set of instruments adapted from those originally designed for humans, i.e., a vectis (for supporting the lens nucleus) and a trisector (for cutting the nucleus), whose tips were alonged by

\footnotetext{
${ }^{16}$ Thionembutal $^{\circledR}$ - Abbott

${ }^{17}$ Halothane - Cristália

${ }^{18} \mathrm{PVPI}^{\circledR}$ - Geyer

${ }^{19}$ Trypan blue dye - Ophthalmos

${ }^{20}$ Ringer with sodium lactate - JR Indústria Farmacêutica SA

${ }^{21}$ Adrenaline - Hipolabor

${ }^{22}$ Heparin 5000/5ml - Cristália

${ }^{23}$ Methylcellulose 2\% - Ophthalmos

${ }^{24} 27 \mathrm{G}$ gingival needle - B-D
}

$3 \mathrm{~cm}$ (Fig. 2), starting from the equatorial zone in the direction of the meeting point of the suture lines. The nucleus was extracted using an irrigated Snellen loop and an Arruga crochet. Then, the remaining cortical masses and viscoelastic substance were removed and the cornea was closed with simple interrupted 7-0 polyglactin 910 sutures $^{25}$. The anterior chamber was then filled with lactated Ringer's solution ${ }^{20}$. A temporary palpebral cannula was introduced to facilitate the administration of topical medications and to avoid forced manipulation of the eyelid during eyedrop instillation.

During the immediate postoperative period, $1 \mathrm{ml}$ betamethasone $^{26}$ was subconjunctivally given in a single dose. In addition, intramuscular flunixin meglumine $^{27}(1 \mathrm{mg} / \mathrm{kg})$ and penicillin $\mathrm{G}$ benzathine, potassium, procaine, streptomycin sulfate, and dihydrostreptomycin ${ }^{28}$ at the dose of $30,000 \mathrm{IU} / \mathrm{kg}$ were administered once daily for three consecutive days after surgery. Tobramycin ${ }^{10}$, diclofenac sodium ${ }^{12}$, and prednisolone $^{13}$ eyedrops were continued to be instilled five times per day for a minimum period of one month. Phenylephrine ${ }^{9}$ was maintained for 10 days at intervals of $8 \mathrm{~h}$. Atropine eyedrops ${ }^{8}$ were instilled twice daily for the first three postoperative days. To protect the operated eyes, protective covers appropriate for horses were used throughout the postoperative period.

Animal six was excluded from the analysis due to the occurrence of ocular trauma followed by panophthalmitis 10 days after surgery. In this individual, the formation of fibrin in the anterior chamber adhering to the iris was observed on postoperative day five, and the onset of a posterior capsular cataract was noted on day eight. Ocular trauma followed by panophthalmitis occurred on postoperative day nine.

\section{RESULTS}

The technique proposed was found to be feasible, permitting the removal of the fragmented crystalline nucleus through a relatively small corneal incision. The $29-\mathrm{mm}$ long $27 \mathrm{~g}$ gingival

\footnotetext{
${ }^{25}$ Vicryl $^{\circledR}$ 7-0 Ethicon - Johnson \& Johnson

${ }^{26}$ Diprobeta $^{\circledR}$ - Bunker

${ }^{27}$ Banamine $^{\circledR}$ - Schering-Plough

${ }^{28}$ Pentabiotic $^{\circledR}$ - Fort Dodge
} 
needle permitted the execution of the desired capsulotomy that comprised the whole circumference of the anterior capsule. Using adapted instruments, originally designed for application to humans (vectis and trisector), the nucleus could be cut in the midline and divided into three parts, thus facilitating removal of the fragments through an approximately $3 \mathrm{~cm}$ incision, with minimal or no collapse of the anterior chamber (Fig. 3). The palpebral cannulae were removed on postoperative day 15 because the eyelid started to show signs of reaction to the implanted material.

Qualitative-quantitative analysis revealed a reduction of intraocular pressure to values of 7 to $10 \mathrm{mmHg}$ in all operated eyes within the first postoperative days. These values returned to normal levels of 18 to $25 \mathrm{mmHg}$ around eight days after the intervention, and remained at these levels for the remaining assessment period.

Photophobia was observed in all cases and it was mild $(+)$ in animals one, four, and five and moderate in animals two and three. These signs gradually disappeared with time.

Blepharospasm was moderate $(++)$ in animals two, three, and five, mild ( + ) in animal four, and absent in animal one, and disappeared on average 10 days after the surgical procedure. Animal 5 again presented blepharospasm 25 days after surgery and developed phthisis bulbi on day 30 .

Epiphora was absent in animals one, two, and four. Moderate $(++)$ epiphora was observed in animals three and five during the first postoperative week and had disappeared in animal three on day 15 and in animal five on day 7. Moderate $(++)$ mucopurulent secretion was only observed in animal five, four days after surgery and had disappeared on day 15 .

Ophthalmoscopy was only possible in animals one and four. Animal one presented normal vision and a menace reflex from the first days to the 12th postoperative day, with the fundus of the eye being normal. The formation of fibrin was subsequently observed, which was organized in the pupillary axis (Fig. 4). In animal four, funduscopy was normal and the blinking reflex to threat and consensual pupillary reflex were present throughout the postoperative period. In the other animals, examination of the fundus of the eye was not possible because of opacification of the transparent media.

Corneal edema was observed on day 7 in animals one, two, and four only in the regions close to the corneal sutures. Animal one presented generalized mild $(+)$ edema on day 15 , except for the temporal region where edema was intense as a result of fibrin adhesion to the corneal endothelium. In animal three, moderate $(++)$ corneal edema was observed ony day 17 , and it was the result of superficial ulcerative keratitis due to spastic entropion. In animal five, the cornea continued to be transparent until the onset of intense $(+++)$ uveitis, accompanied by ciliary injection on postoperative day 25, which progressed to phthisis bulbi on day 35 (Fig. 5).

All studied animals presented varying levels of fibrin in the anterior chamber. Animals one and two continued to show normal vision accompanied by fibrin synechiae in the iris for the first 12 postoperative days, subsequently followed by a network-like arrangement of fibrin in the pupillary axis. In animal three, mild $(+)$ fibrin formation and anterior chamber flare were observed up to day 15 , when these signs became more intense $(++)$ and associated with corneal edema. On day 35, remission of superficial keratitis and a reduction of corneal edema were noted, allowing to observe the formation of fibrin in the anterior chamber and a posterior capsular cataract. In animal four, the anterior chamber was clean throughout the assessment period, with the observation of small foci of fibrin formation in the ventronasal region adhered to the iris (Fig. 6). In animal five, increased fibrin formation was already observed during surgery, which was organized in the anterior chamber by postoperative day 2. A gradual decrease in fibrin formation, occupying half of the cornea, was observed after 20 days. 


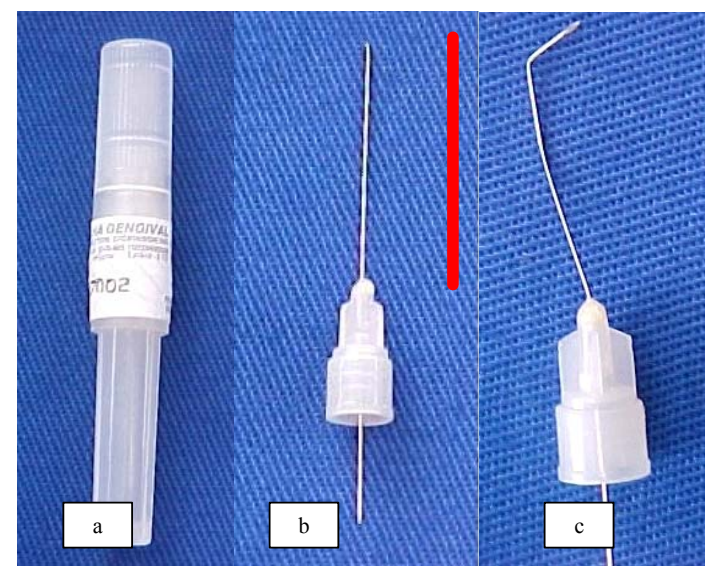

Figure 1. Image illustrating the $27 \mathrm{G}$ gingival needle inside its package (a), outside the package (b) (its 29$\mathrm{mm}$ length is indicated in red), and with its mechanically bent tip (c).

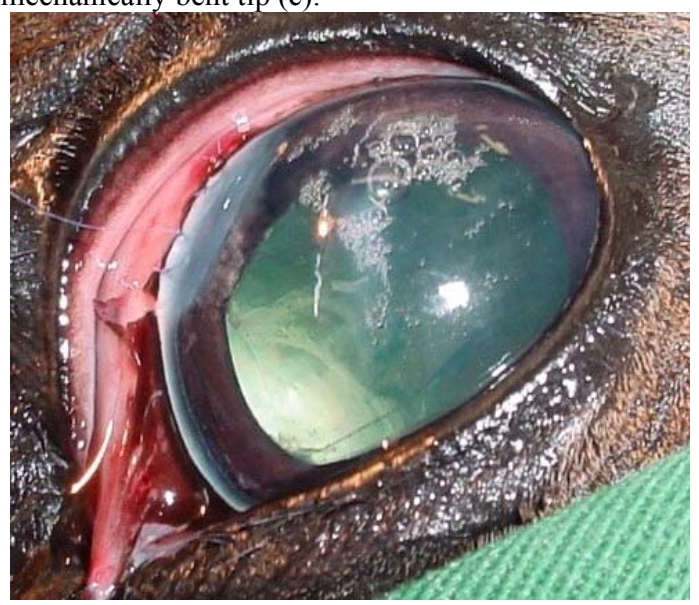

Figure 3. Image of the left eye of an adult horse obtained during the immediate postoperative period. Note the free pupillary axis, reflex of the fundus of the eye, and small fibrin formation in the anterior chamber.

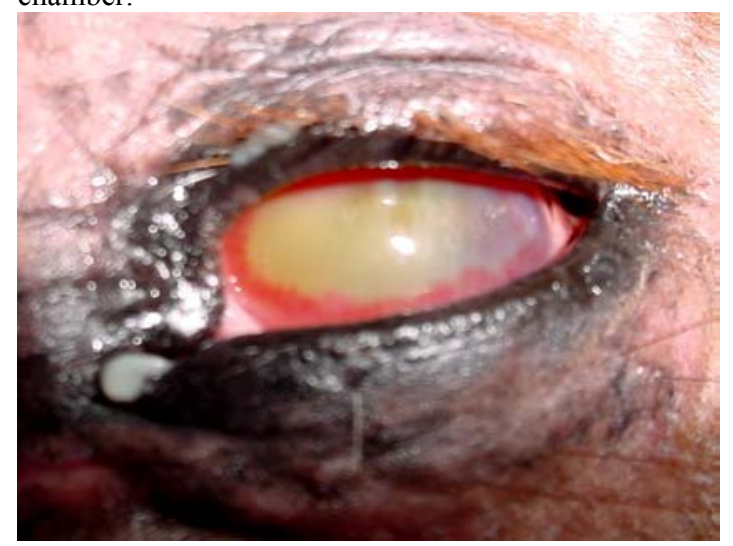

Figure 5. Image of the left eye of an adult horse. Note the presence of uveitis with ciliary injection at $360^{\circ}$, intense flare, and fibrin formation, with the beginning of phthisis bulbi (postoperative day 40).

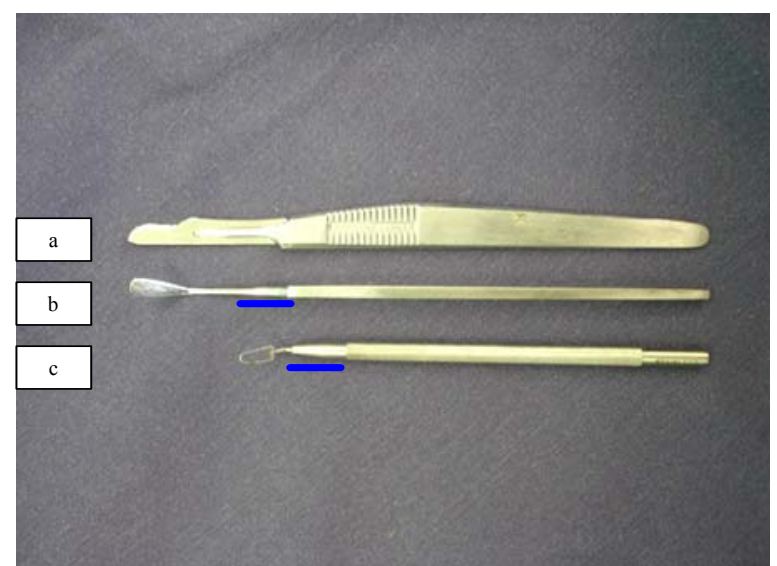

Figure 2. Image illustrating the $\mathrm{n}^{\mathrm{o}} 11$ surgical knife (a) and the instruments which were $3 \mathrm{~cm}$ longer at the tips (indicated in blue) including the vectis (b) and trisector (c).

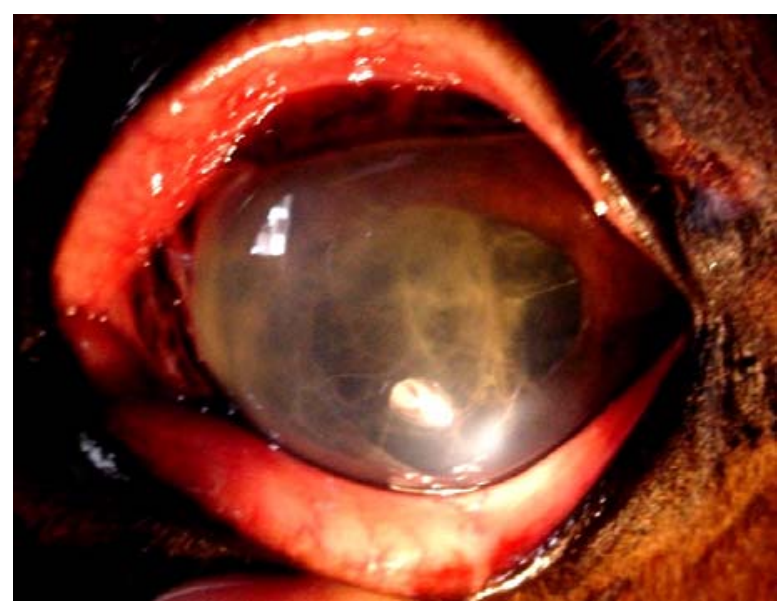

Figure 4. Image of the left eye of an adult horse 10 days after surgery. Note the formation of fibrin close to the pupillary axis (arrow).

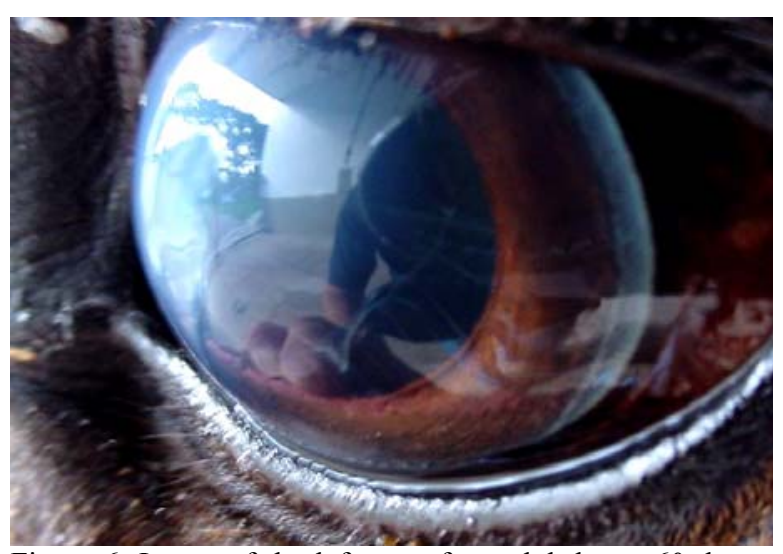

Figure 6. Image of the left eye of an adult horse 60 days after surgery. Note the clean anterior chamber, normal iris, and transparent cornea. 


\section{DISCUSSION}

The traditional technique for extracapsular cataract extraction consists of anterior capsulorrhexis and removal of the whole cortex and nucleus. The procedure requires an extensive corneal incision of approximately 160 to 180 degrees, which predisposes to collapse of the anterior chamber, increased trauma, and a higher frequency of postoperative iridocyclitis (McLaughlin et al., 1992). Modification of this technique and the use of instruments adapted to the eyes of adult horses permitted the easy removal of the crystalline nucleus. A $29-\mathrm{mm}$ long $27 \mathrm{G}$ gingival needle (Girotto et al., 2000) was used for capsulotomy, comprising the whole circumference of the lens which ranges from 30 to $35 \mathrm{~mm}$ in horses. In dogs, a $13-\mathrm{mm}$ long $4.5 \mathrm{G}$ needle is employed for the same purpose, i.e., to lesion the anterior capsule for posterior capsulorrhexis (Glover and Constantinescu, 1997).

The instruments originally designed for use in humans and adapted here (vectis and trisector) facilitated the division of the nucleus into three parts and its extraction through a relatively small incision, with minimal or no collapse of the anterior chamber. These instruments are widely used in humans and were elongated to adapt them to the dimensions of the eye of the adult horse, with satisfactory results.

Postoperative intraocular pressure was evaluated in all animals. An acute increase of intraocular pressure might be observed in horses after intraocular interventions but is less frequent than in dogs. In horses, the occurrence of glaucoma is uncommon (Kruiningen, 1964; Millichamp and Dziezyc, 2000). In the present study, a reduction of intraocular pressure was observed during the acute postoperative phase, followed by a gradual return to normal values after around of one week in all animals.

Complications after cataract surgery in horses are mainly the result of postoperative uveitis. Uveitis leads to the occurrence of corneal edema, the formation of a fibrinous pupillary membrane, and phthisis bulbi, which represent frequent sequelae in animals that develop severe iridocyclitis or panophthalmitis (McLaughlin et al., 1992; Matthews, 2004). Additional complications include corneal edema resulting from endothelial damage induced by excessive intraocular irrigation or contact with the instruments. Other reported complications are cataracts secondary to opacification of the remnant anterior capsule or rests of cortical material and migration of pigmented cells and fibroblasts to the posterior capsule of the lens (McLaughlin et al., 1992; Matthews, 2004). In the present study, a posterior capsular cataract was observed in two animals, 10 and 20 days after surgery.

Corneal edema is common during the acute postoperative phases and is more frequent along the incision line and at sites where fibrin coagula adhere to the corneal endothelium (McLaughlin et al., 1992). Corneal edema is more persistent in horses compared to dogs, and is still more frequent in adult animals (Millichamp and Dziezyc, 2000). In the present study, corneal edema was observed along the incision line of all operated animals and in other areas of the cornea in some individuals, coinciding with sites of fibrin adherence to the endothelium. These adherences were observed in two animals. Another possible complication is superficial keratitis (Hardman et al., 2001), which was identified in one animal and was the result of spastic entropion.

Aqueous flare is normally observed within the first postoperative days. Fibrin becomes organized forming coagula that often adhere to the iris, normally in its axial portion (McLaughlin et al., 1992). In the present study, fibrinogenesis was detected in all operated animals, but at variable intensities.

Cataract surgery in adult horses continues to be a great challenge. There is no doubt that better outcomes are obtained in animals younger less than one year (Wilkie, 1998; Rebhun, 1999; Matthews, 2004). Despite all techniques available, phacoemulsification is the method of choice for application to most species; however, adaptations are required for adult horses (Dziezyc et al., 1991).

\section{CONCLUSIONS}

The present results demonstrate that extracapsular cataract extraction can be easily conducted in horses using the adapted 
instruments. However, additional care should be taken, notably with respect to the management of postoperative uveitis, so that better outcomes can be obtained.

\section{REFERENCES}

BROOKS, D.E. Oftalmologia Eqüina. In: GELATT, K.N. (Ed). Manual de oftalmologia veterinária. São Paulo: Manole, 2003. p.337376.

DZIEZYC, J.; MILLICHAMP, N.J.; KELLER, C.B. Use of phacofragmentation for cataract removal in horses: 12 cases(1985-1989). J. Am. Vet., v.198, p.1774-1778, 1991.

GIROTTO, M.A.; VOLPATO, M.C.; RANALI, J. Avaliação da padronização de agulhas anestésicas odontológicas comercializadas no Brasil. Pesqu. Odontol. Bras., v.4, p.294-299, 2000.

GLOVER, T.D.; CONSTANTINESCU, M.G. Surgery for cataracts. Vet. Clin. N. Am.: Small Anim. Pract., v.27, p.1143-1173, 1997.

HARDMAN, C.; McILNAY, T.R.; DUGAN, S.J. Phacofragmentation for morganian cataract in a horse. Vet. Ophthalmol., v.4, p.221-225, 2001.

KRUININGEN, H.J.V. Intracapsular cataract extraction in the horse. J. Am. Vet. Med. Assoc., v.145, p.773-785, 1964.

MATTHEWS, A.G. The lens and cataracts. Vet. Clin. N. Am.: Equine Pract., v.20, p.393-415, 2004.
McLAUGHLIN, S.A.; WHITLEY, R.D.; GILGER, B.C. Diagnosis and treatment of lens diseases. Vet. Clin. N. Am.: Equine Pract., v.8, p.575-585, 1992.

MILLICHAMP, N.J.; DZIEZYC, J. Cataract phacofragmentation in horses. Vet. Ophthalmol., v.3, p.157-164, 2000.

REBHUN, W.C. Diseases of the lens and vitreous. In: COLAHAN, P.; MAYHEW, I.G.; MERRITT, A.M. et al. (Eds). Equine medicine and surgery. 5.ed. St. Louis: Mosby, 1999. v.2.

TURNER, A.G. Ocular conditions of neonatal foals. Vet. Clin. N. Am. Equine Pract., v.20, p.429-440, 2004.

WHITLEY, R.D.; MEEK, L.A.; MILLICHAMP, N.J. et al. Cataract surgery in the horse: a review of six cases. Equine Vet. J., v.10, suppl., p.85-90, 1990.

WHITLEY, R.D.; MOORE, C.P.; SLONE, D.E. Cataract surgery in the horse: a review. Equine Vet. J., v.2, suppl., p.127-134, 1983.

WILKIE, D.A. Equine ophthalmology. In: REED, S. M.; BAYLY, W.M. Equine internal medicine. Philadelphia: W.B. Saunders, 1998. p.756-757,

WOUK, A.F.P.F., SOUZA, A.L.G., MICHELOTTO JR., P.V. et al. Utilização dos Sistemas manuais de irrigação-aspiração e fragmentação-aspiração para correção de catarata em potros - Relato de 14 casos. In: CONGRESSO INTERNACIONAL DE CAVALOS DE ESPORTE, 22., 2003, Curitiba. Anais... Curitiba: CICADE, 2003. 